\title{
Influence of Bio-Fertilizers on Morphological, Yield and Quality of Coriander cv. (Coriandrum sativum L.)
}

\author{
Roshan Lal Sahu ${ }^{1^{*}}$ and Hansa Sahu ${ }^{2}$ \\ ${ }^{1}$ KVK, Anjora (Durg), IGKV Raipur, India \\ ${ }^{2}$ Department of Plant Physiology, IGKV Raipur, India
}

*Corresponding author

Keywords

Coriander, PSB, AzospirillumAzoto bacter, Morphology, yield

Article Info

Accepted: 05 April 2020 Available Online: 10 May 2020

\section{A B S T R A C T}

A field study was carried out in Horticulture Research Farm, I.G.K.V. Raipur (C.G.) during rabi season 2007-08. The results indicated that vegetative growth contributing characters (leaf area index, fresh and dry weight per plant were influenced by combination of $100 \% \mathrm{~K}$ and $75 \% \mathrm{NP}$ along with Azotobacter, Azospirillum and PSB $\left(\mathrm{T}_{8}\right)$. Yield contributing characters (like number of seed per umbellet, 1000-seed weight (g), total no of seed per plant $(\mathrm{g})$ and seed yield $(\mathrm{q} / \mathrm{ha})$ maximum in $\left(\mathrm{T}_{8}\right)$ were given better performance respectively over all the treatments. Hence it is concluded that the treatment (T8) $75 \% \mathrm{NP}+100 \% \mathrm{~K}+$ Azotobacter, Azospirillum and PSB was found economically B: C ratio (1:4.9) best than all the treatments studied in this investigation.

\section{Introduction}

Coriander (Coriandrum sativum L.) is an annual herb, generally called "Dhania" belongs to family Apiaceae (Umbelliferae) with diploid chromosome number $(2 \mathrm{n}=22)$. Coriander is one of the major seed spices grown in India. It is one of the earliest spices known to mankind for its intrinsic and fragrant qualities of both seed and leaves.

Biofertilzers are less expensive, eco-friendly and sustainable likely to assume greater significance as a compliment or supplement to inorganic fertilizers (Malhotra et al., 2006). Biofertilizers are the products which contain living cells of different types of microorganisms that have an ability to convert nutritionally important elements from unavailable to available form through biological processes.

\section{Materials and Methods}

The experiment was carried out during Rabi season 2007-08 at the Horticulture Research 
Farm, Department of Horticulture, Indira Gandhi KrishiVishwavidyalaya (I.G.K.V.) Raipur. Raipur is situated in the central eastern part of Chhattisgarh and lies at $21^{0} 16^{\text {' }}$ $\mathrm{N}$ latitude and $81^{\circ} 26^{\prime} \mathrm{E}$ longitudes with an altitude of $289.59 \mathrm{~m}$ above the mean sea level. The total rainfall of the season was about $24.0 \mathrm{~mm}$ of rainfall during its growth period. The temperature ranges during the crop growth period varied between $18.0^{\circ} \mathrm{C}$ $26.67^{\circ} \mathrm{C}$.

The texture of experimental soil was loamy sand and with subsurface sandy clay loam, the experiment was planted in Randomized Block Design (RBD) with the three replications. There were fifteen treatments comprising of different bio-fertilizers with and without inorganic fertilizers (NPK).

Pant Haritama an improved variety of coriander developed through intensive selection from Bulgarian material by G.B. Pant Agriculture University Pantnagar, was used in the present investigation.

\section{Results and Discussion}

\section{Morphological characters}

Morphological characters such as leaf area index, fresh weight and dry weight of plants (table 1) showed significant variation with different biofertilizers. Treatment $\left(\mathrm{T}_{8}\right)$ i.e., combination of recommended $\mathrm{K}$ and $75 \% \mathrm{NP}$ along with Azospirillum, Azospirillum and PSB recorded highest leaf area index (0.19, 0.89 and 0.33 at 45,90 DAS and at harvest), fresh weight $(9.75,25.95$ and 47.48 at 45,90 DAS and at harvest) and dry weight of plants (4.06 g, $7.42 \mathrm{~g}$ and $17.83 \mathrm{~g}$ at 45, 90 DAS and at harvest). Wange et al., (1995) in garlic Treatment $\left(T_{1}\right)$ with 60:40:40 kg/ha NPK recorded the minimum leaf area index per plant, $(0.15,0.84$ and 0.07 at 45,90 DAS and at harvest), fresh weight $(6.85,15.76$ and 38.23 at 45,90 DAS and at harvest) and dry weight of plants $(2.39 \mathrm{~g}, 5.37 \mathrm{~g}$ and $11.45 \mathrm{~g}$ at 45, 90 DAS and at harvest). Some results were also observed by Valadabadi (2011) in Nigella sativa.

\section{Quality characters}

Essential oil content was also showed significant variation among the different biofertilizers. The treatment $\left(\mathrm{T}_{8}\right)$ recorded the maximum essential oil content in seeds $(0.96$ $\%)$ and followed by the treatment $\left(\mathrm{T}_{9}\right)(0.91$ $\%$ ) and $\mathrm{T}_{6}, \mathrm{~T}_{7}$ and $\mathrm{T}_{10}$ treatments were also $a t$ par with each other $(0.91 \%$ each $)$. However, the lowest essential oil content $(0.84 \%)$ was recorded in the $\mathrm{T}_{2}$ and $\mathrm{T}_{14}$ treatments were also at par with each other

Similar observation was recorded by Rahimi et al., (2009), Shivalingappa (1998) also reported that plants inoculated with Azospirillum, Azospirillum and VAM along with NPK 75: 37.5: $50 \mathrm{~kg}$ per hectare was recorded more concrete yield in tuberose.

\section{Yield and yield attributes}

The yield and yield attributing characters, such as number of seed per umbellet (74.25), total number of seeds per plant (1720.36), weight of 1000 seeds $(8.50 \mathrm{~g})$ and seed yield (23.78 q/ha) (Table 2) were also showed significant variation among the different biofertilizers.

The treatment $\left(\mathrm{T}_{8}\right)$ was recorded maximum and it significantly different from other treatments. Ali et al., (2009), in coriander and Belimov et al., (1995) in barley. 
Table.1 Influence of bio-fertilizers with graded levels of fertilizers on leaf area index, Fresh weight of plantand Dry weight of plant in coriander cv. Pant Haritama

\begin{tabular}{|c|c|c|c|c|c|c|c|c|c|}
\hline \multirow[t]{2}{*}{ Treatments } & \multicolumn{3}{|c|}{ Average leaf area index } & \multicolumn{3}{|c|}{$\begin{array}{l}\text { Fresh weight of plant } \\
\text { (g) }\end{array}$} & \multicolumn{3}{|c|}{ Dry weight of plant (g) } \\
\hline & $\begin{array}{l}45 \\
\text { DAS }\end{array}$ & $\begin{array}{l}90 \\
\text { DAS }\end{array}$ & $\begin{array}{l}\text { At } \\
\text { harvest }\end{array}$ & $\begin{array}{l}45 \\
\text { DAS }\end{array}$ & $\begin{array}{l}90 \\
\text { DAS }\end{array}$ & $\begin{array}{l}\text { At } \\
\text { harvest }\end{array}$ & $\begin{array}{l}45 \\
\text { DAS }\end{array}$ & $\begin{array}{l}90 \\
\text { DAS }\end{array}$ & $\begin{array}{l}\text { At } \\
\text { harvest }\end{array}$ \\
\hline T1 60:40:40 (RDF) (control) & 0.15 & 0.84 & 0.07 & 6.85 & 15.76 & 38.23 & 2.39 & 5.37 & 11.45 \\
\hline T2 $75 \% \mathrm{~N}+100 \% \mathrm{PK}+$ Azospirillum & 0.16 & 0.86 & 0.08 & 7.87 & 19.54 & 42.05 & 2.91 & 6.40 & 14.32 \\
\hline $\begin{array}{l}\text { T3 75\% N + 100\% PK + } \\
\text { Azospirillum }\end{array}$ & 0.17 & 0.89 & 0.08 & 8.14 & 19.79 & 42.41 & 2.95 & 6.56 & 14.44 \\
\hline T4 $75 \% \mathrm{P}+100 \% \mathrm{NK}+\mathrm{PSB}$ & 0.18 & 0.91 & 0.09 & 8.38 & 20.28 & 42.59 & 3.02 & 6.55 & 14.46 \\
\hline $\begin{array}{l}\text { T5 } \quad 75 \% \text { N } 100 \% \text { PK + } \\
\text { Azospirillum }+ \text { Azospirillum }\end{array}$ & 0.17 & 0.89 & 0.09 & 8.73 & 20.71 & 43.51 & 3.23 & 6.75 & 14.79 \\
\hline $\begin{array}{l}\text { T6 } 75 \% \text { NP }+100 \% \mathrm{~K}+ \\
\text { Azospirillum + PSB }\end{array}$ & 0.18 & 0.85 & 0.31 & 9.13 & 21.03 & 43.12 & 3.61 & 6.82 & 14.58 \\
\hline $\begin{array}{l}\text { T7 } 75 \% \mathrm{NP}+100 \% \mathrm{~K}+ \\
\text { Azospirillum }+\mathrm{PSB}\end{array}$ & 0.17 & 0.96 & 0.08 & 8.53 & 20.47 & 43.22 & 3.16 & 6.65 & 14.74 \\
\hline $\begin{array}{l}\text { T8 } 75 \% \mathrm{NP}+100 \% \mathrm{~K}+ \\
\text { Azospirillum }+ \text { Azospirillum }+ \\
\text { PSB }\end{array}$ & 0.19 & 0.89 & 0.33 & 9.73 & 25.95 & 47.48 & 4.06 & 7.42 & 17.83 \\
\hline $\begin{array}{l}\text { T9 } 50 \% \mathrm{~N}+100 \% \mathrm{PK}+ \\
\text { Azospirillum }\end{array}$ & 0.17 & 0.90 & 0.09 & 8.27 & 20.55 & 45.26 & 3.21 & 6.55 & 14.66 \\
\hline $\begin{array}{l}\text { T10 } 50 \% \mathrm{~N}+100 \% \mathrm{PK} \\
+ \text { Azospirillum }\end{array}$ & 0.16 & 0.91 & 0.10 & 8.59 & 20.54 & 43.79 & 3.33 & 6.64 & 14.98 \\
\hline T11 $50 \% \mathrm{P}+100 \% \mathrm{NK}+\mathrm{PSB}$ & 0.17 & 0.89 & 0.09 & 9.24 & 20.81 & 43.81 & 3.30 & 6.71 & 14.86 \\
\hline $\begin{array}{l}\text { T12 } 50 \% \mathrm{~N}+100 \% \mathrm{PK}+ \\
\text { Azospirillum + Azospirillum }\end{array}$ & 0.16 & 0.89 & 0.08 & 7.52 & 19.27 & 42.86 & 2.64 & 6.24 & 13.65 \\
\hline $\begin{array}{l}\text { T13 50\% NP + } 100 \% \mathrm{~K}+ \\
\text { Azospirillum + PSB }\end{array}$ & 0.16 & 0.84 & 0.08 & 8.04 & 18.58 & 42.57 & 2.93 & 6.41 & 13.3 \\
\hline $\begin{array}{l}\text { T14 50\% NP + 100\% K + } \\
\text { Azospirillum + PSB }\end{array}$ & 0.17 & 0.85 & 0.09 & 8.30 & 19.66 & 41.74 & 3.14 & 6.59 & 13.4 \\
\hline $\begin{array}{l}\text { T15 50\% NP +100\% K + } \\
\text { Azospirillum + Azospirillum }+ \\
\text { PSB }\end{array}$ & 0.18 & 0.882 & 0.1 & 9.26 & 21.47 & 43.61 & 3.56 & 6.94 & 14.38 \\
\hline Mean & 0.169 & 0.034 & 0.118 & 8.44 & 20.29 & 43.08 & 3.169 & 6.57 & 14.389 \\
\hline SEm \pm & 0.009 & 0.096 & 0.079 & 0.152 & 0.137 & 0.82 & 0.031 & 0.028 & 0.032 \\
\hline CD at $5 \%$ & 0.027 & BB & 0.22 & 0.427 & 0.38 & 2.28 & 0.087 & 0.079 & 0.08 \\
\hline
\end{tabular}


Table.2 Influence of bio-fertilizers with graded levels of fertilizers on essential oil content of seeds, Weight of 1000seeds (g), No. of seed per umbellet, Total no. of seeds per plant, seed yield per hectare in coriander cv. Pant Haritama

\begin{tabular}{|c|c|c|c|c|c|}
\hline Treatments & \begin{tabular}{lr}
\multicolumn{2}{l}{ Essential } \\
oil & content \\
in r seeds \\
$(\%)$
\end{tabular} & $\begin{array}{l}\text { Weight of } \\
\text { 1000seeds } \\
\text { (g) }\end{array}$ & $\begin{array}{l}\text { No. of seed } \\
\text { per } \\
\text { umbellet }\end{array}$ & $\begin{array}{l}\text { Total no. of } \\
\text { seeds per } \\
\text { plant }\end{array}$ & $\begin{array}{l}\text { Seed } \\
\text { yield/hect } \\
\text { are }\end{array}$ \\
\hline T1 60:40:40 (RDF) (control) & 0.85 & 7.64 & 56.21 & 842.32 & 10.27 \\
\hline T2 $75 \% \mathrm{~N}+100 \% \mathrm{PK}+$ Azospirillum & 0.84 & 7.71 & 58.02 & 1194.25 & 15.18 \\
\hline T3 $75 \% \mathrm{~N}+100 \% \mathrm{PK}+$ Azospirillum & 0.86 & 7.82 & 59.21 & 1296.73 & 17.52 \\
\hline T4 $75 \% \mathrm{P}+100 \% \mathrm{NK}+\mathrm{PSB}$ & 0.89 & 7.71 & 64.03 & 1303.72 & 16.82 \\
\hline T5 $75 \%$ N $100 \%$ PK + Azospirillum + Azospirillum & 0.91 & 8.01 & 60.39 & 1426.37 & 19.04 \\
\hline T6 $75 \% \mathrm{NP}+100 \% \mathrm{~K}+$ Azospirillum + PSB & 0.89 & 7.80 & 60.12 & 1545.70 & 20.04 \\
\hline T7 $75 \% \mathrm{NP}+100 \% \mathrm{~K}+$ Azospirillum +PSB & 0.85 & 8.07 & 58.93 & 1298.99 & 17.44 \\
\hline $\begin{array}{l}\text { T8 } 75 \% \mathrm{NP}+100 \% \mathrm{~K}+\text { Azospirillum }+ \text { Azospirillum } \\
+ \text { PSB }\end{array}$ & 0.96 & 8.50 & 74.25 & 1720.36 & 23.78 \\
\hline T9 $50 \% \mathrm{~N}+100 \% \mathrm{PK}+$ Azospirillum & 0.89 & 7.72 & 61.81 & 1562.94 & 20.00 \\
\hline T10 $50 \% \mathrm{~N}+100 \%$ PK +Azospirillum & 0.90 & 7.73 & 66.28 & 1601.26 & 20.00 \\
\hline T11 $50 \% \mathrm{P}+100 \% \mathrm{NK}+\mathrm{PSB}$ & 0.91 & 8.00 & 61.94 & 1545.36 & 19.51 \\
\hline $\begin{array}{l}\text { T12 } 50 \% \mathrm{~N}+100 \% \mathrm{PK}+\text { Azospirillum+ } \\
\text { Azospirillum }\end{array}$ & 0.89 & 7.71 & 64.25 & 1126.41 & 14.45 \\
\hline T13 $50 \% \mathrm{NP}+100 \% \mathrm{~K}+$ Azospirillum + PSB & 0.89 & 7.50 & 61.64 & 1341.36 & 17.7 \\
\hline T14 $50 \% \mathrm{NP}+100 \% \mathrm{~K}+$ Azospirillum + PSB & 0.84 & 7.74 & 62.04 & 1403.89 & 18.0 \\
\hline $\begin{array}{l}\text { T15 } 50 \% \mathrm{NP}+100 \% \mathrm{~K}+\text { Azospirillum }+ \text { Azospirillum } \\
+ \text { PSB }\end{array}$ & 0.85 & 7.83 & 69.09 & 1599.21 & 20.4 \\
\hline Mean & 0.882 & 7.83 & 62.61 & 1388.77 & 18.01 \\
\hline $\mathrm{SEm} \pm$ & 0.034 & 0.019 & 0.028 & 22.26 & 0.248 \\
\hline CD at $5 \%$ & 0.096 & 0.052 & 0.078 & 61.71 & 0.688 \\
\hline
\end{tabular}

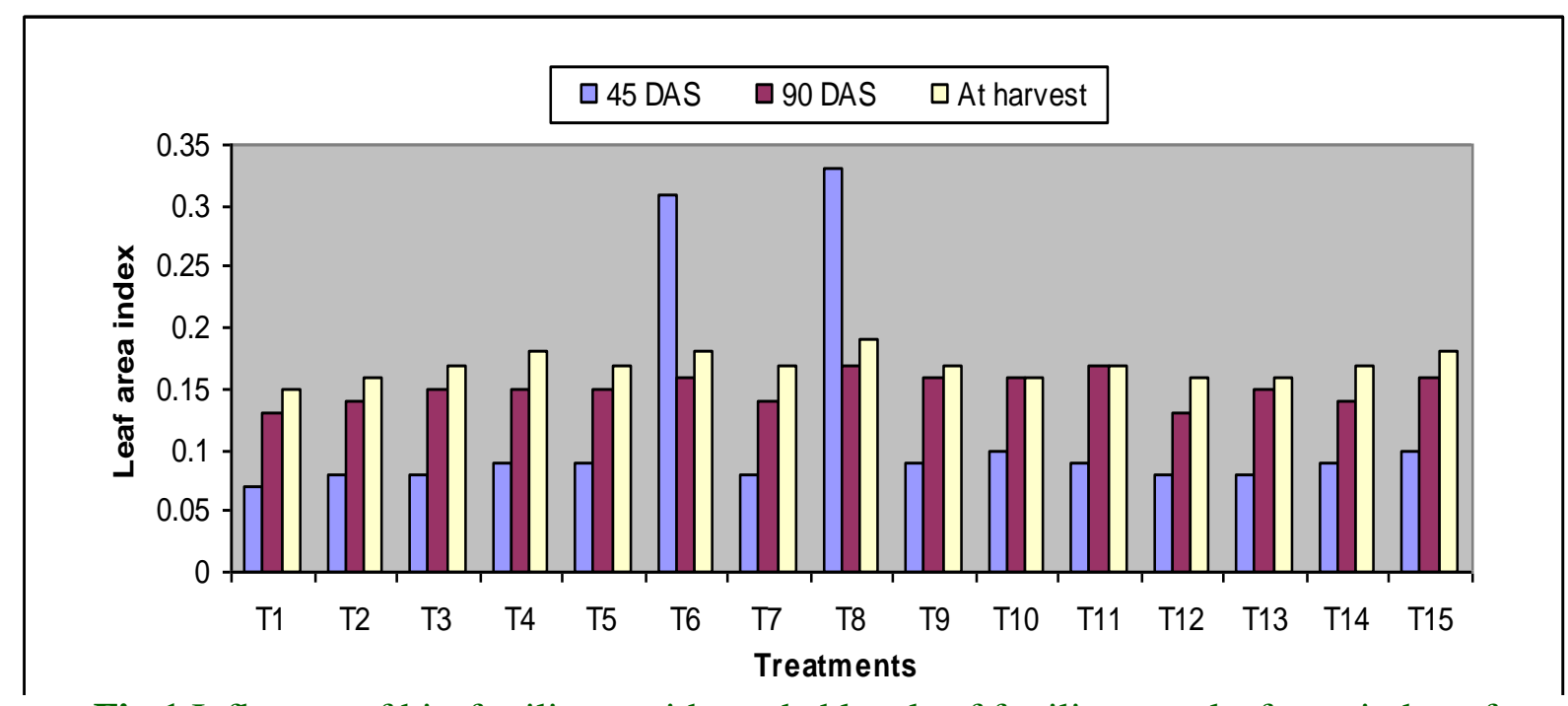

Fig.1 Influence of bio-fertilizers with graded levels of fertilizers on leaf area index of coriander cv. Pant Haritama 


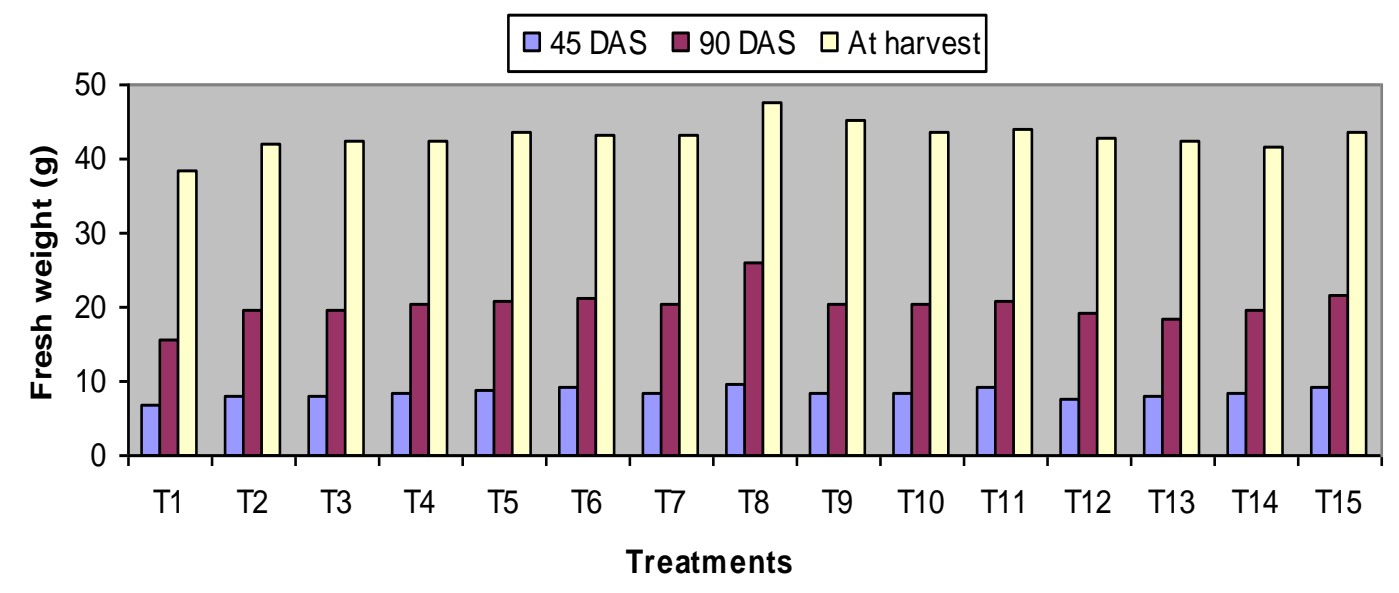

Fig.2 Influence of bio-fertilizers with graded levels of fertilizers on fresh weight of coriander cv. Pant Haritama

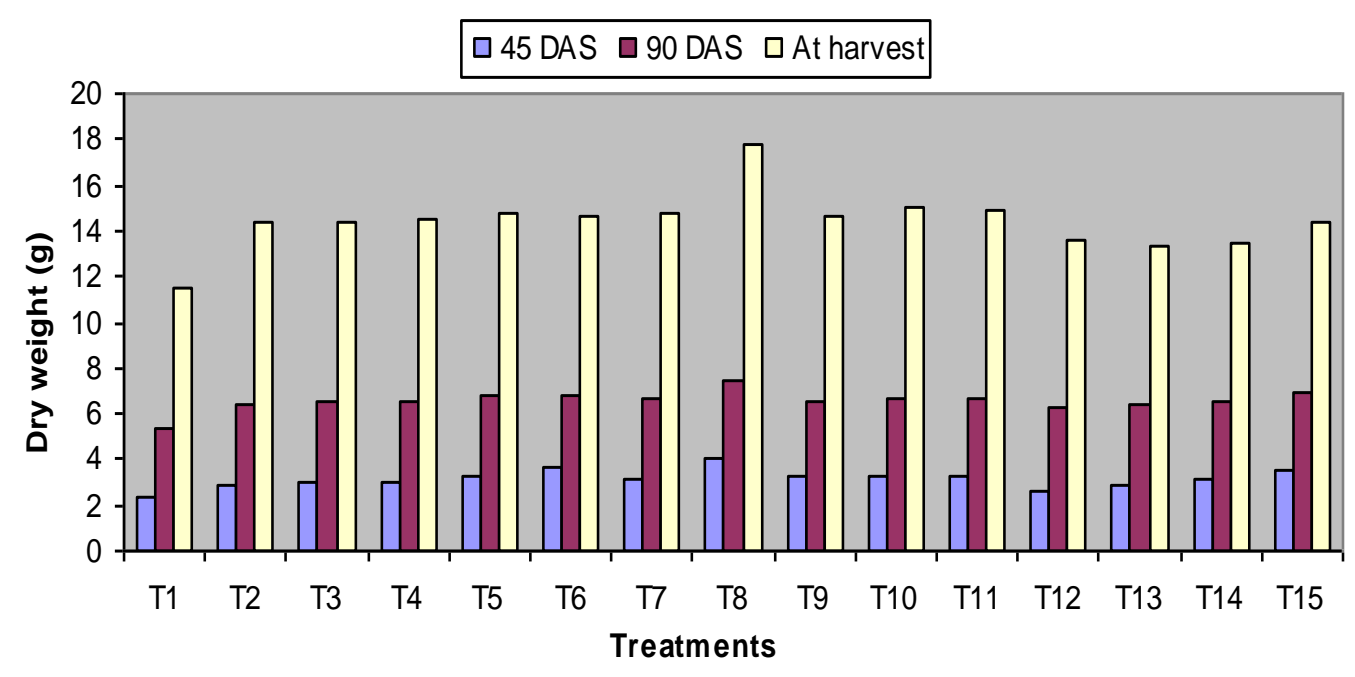

Fig.3 Influence of bio-fertilizers with graded levels of fertilizers on dry weight of plants of coriander cv. Pant Haritama

However, the minimum number of seed per umbellet (56.21), total numbers of seeds per plant (842.32), weight of 1000 seeds $(7.50 \mathrm{~g})$ and seed yield (10.27 q/ha).Roy and Singh, (2006) in barley and Darzi et al., (2001) in Fennel.

\section{References}

Ali, F.S. Saad, O.A. and Abdul-Mohsin E. 2009. Optimisation of nitrogen fertilizer level for maximum colonization of mycorrhizae on roots of coriander plants. African Crop Science Conference Proceedings, Vol. 9. pp. $117-122$.

Belimov, A.A., A.P. Kojemiakov and C.V. Chuvarliyeva 1995. Interaction between barley and mixed cultures of nitrogen fixing and phosphate - solubilising bacteria. Plant and Soil, 173: 29-37.

Chen, J. 2006. The combined use of chemical and organic fertilizers and biofetilizer for crop growth and soil fertility. In : 
International Workshop on Sustained Management of the Soil Rhizosphere System for Efficient Crop Production and Fertilizer Use.16 - 20 October, Thailand.

DarziMT, KhodabandehN, Haj SeyedHadi MR,YasaN.2001. Effects of sowing date and plant density on seed yield and quantity and quality of active substance of fennel (Foeniculum vulgare). National Congress of Medicinal Plants. Pp:151-152.

Malhotra, S.K. Vashistha, B.B. and Apparao, V.V. 2006. Influence of nitrogen, Azospirillum sp. and farm yard manure on growth yield and incidence of stem gall disease in coriander (Coriandrum sativum L.). Journal of Spices and Aromatic Crops, 15 (2): 115-117

Rahimi, A.R., K, Mashayekhi, S, Amini, E. Soltani 2009. Effect of Mineral vs. Biofertilizer on the Growth, Yield and Essential Oil Content of Coriander
(Coriandrum sativum L.) Medi. Aro. Pla. Sci. Biol., Global Science Books

Roy DK, Singh BP.2006.Effect of level and time of nitrogen application with and without vermicompost on yield, yield attributes and quality of malt barley (Hordeum vulgare). Indian J. Agron., 51:40-42Cocoa, Arecanut and Spices J., 13 (4): 130-133.

Shivalingappa, J., 1998.Influence of biofertilizers o growth, yields and essential oil content in tuberose (Polianthes tuberose L.) M.Sc. (Argil.) Hort. Thesis submitted to University of Agriculture Sciences, Bangalore.

ValadabadiSA,FarahaniHA.2011.Investigatio nofbiofertilizersinfluenceonquantityand qualitycharacteristicsinNigellasativaL.J. Hortic.Forestry.3(3):88-92.

Wange, S.S., 1995. Response of garlic to combined application of bio-fertilizers and fertilizer nitrogen. J. Soils and Crops. 5 (2) 41-43.

\section{How to cite this article:}

Roshan Lal Sahu and Hansa Sahu. 2020. Influence of Bio-Fertilizers on Morphological, Yield and Quality of Coriander cv. (Coriandrum sativum L.). Int.J.Curr.Microbiol.App.Sci. 9(05): 453-458. doi: https://doi.org/10.20546/ijcmas.2020.905.051 